\title{
家畜排せつ物コンポストの低温ガス化プロセスにおける硫黄及び 塩素の放出挙動の分析と固体残椬の脱硫・脱塩への応用
}

\author{
森 勝 伸 ${ }^{\circledR 1}$, 上村 卓寬 ${ }^{1}$, 郡司 文音 ${ }^{1}$, 金子 啓一 ${ }^{1,2}$,

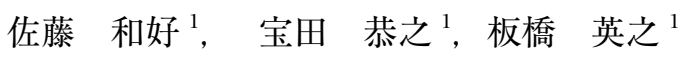

\begin{abstract}
環境に負荷をかけない家畜排せつ物の低温ガス化プロセスの開発に関連し，コンポストを熱分解したと き, ガス化炉内の腐食の原因となる硫黄及び塩素のガス，スス，タールへの放出挙動を調查した．ここでは, 小型熱分解装置により, 還元的雾囲気下において, 各熱分解温度 $\left(500 \sim 900{ }^{\circ} \mathrm{C}\right)$ での豚算コンポス卜 $(\mathrm{PC})$ 及び䳎翼コンポスト（CC）から放出される硫黄及び塩素を分析した．その結果，PC の塩素，CC の硫黄と塩 素は, 熱分解温度の上昇に伴い, ガス，スス及びタールに放出される割合が高くなる傾向を示した．これは， PC と CC の結晶性や硫黄及び塩素の放出源の化学形態に関与するものと考えられる. また, 本研究では, 力 ルシウムを多く含む CCチャーを脱硫・脱塩触媒として応用した，ここでは，PCの下段の触媒層にCC チャーを充填し，PCから放出される硫黄と塩素に対する CCチャーの吸着能を調べた，その結果，放出され た硫黄及び塩素を CCチャーによって保持することができた.これは, CCチャー中のカルシウムとの反応が 関与しているものと考えられる.
\end{abstract}

\section{1 緒言}

家畜排せつ物は国内有機性廃棄物の最大量を保有してお $り$, 家畜の種類, 体重, 給与飼料 (量, 質), 飲水量, 飼育 形態，季節や家畜の体調によって，その質量（1 日 1 頭羽 当たり排せつ量）も大きく変動する. 日本での 1 年間に発 生する家畜排せつ物の量は約 9000 万トンと推計される. 近年は，家畜排せつ物は畜種や飼養形態によって様々な性 状を呈し，それぞれの特性に応じた貯留・搬出及び処理方 法がなされている.

日本では国土が狭く, 都市と農村の混住していることか ら,コンポスト化（たい肥化）処理や浄化処理等が行われ, 諸外国に比べて多様な処理・保管方法が用いられてい る ${ }^{1)}$. 特に, コンポスト化はふん尿などの污物感や悪臭を 軽滅し，取扱いやすいものにでき，土壤や作物にとって安 全で良質な肥料成分を適度に含む栄養分にできることか ら，資源循環型社会の構築に貢献できる方法といえる ${ }^{2) 3}$.

また，コンポスト化以外の利用としては，メタン発䣲技 術) 7) やバイオマスガス化 ${ }^{899)}$ が挙げられる. メタン発酵技 術は, 污泥, 食品残㴡等の含水率が高いバイオマスからエ ネルギーを有効に取り出す技術であり，嫌気的条件下で嫌

\footnotetext{
${ }^{\circledR}$ E-mail : mori@gunma-u.ac.jp

${ }^{1}$ 群馬大学理工学研究院環境創生部門 : 376-8515 群馬県桐生市 天神町 1-5-1

2 株式会社キンセイ産業 : 370-1203 群馬県高崎市矢中町 788
}

気性細菌の作用により, 有機物からメタン $\left(\mathrm{CH}_{4}\right)$ と二酸 化炭素 $\left(\mathrm{CO}_{2}\right)$ を発生させ, ガスエンジン, 燃料電池, ボ イラ等に利用されている，一方，バイオマスガス化はメ夕 ン発酵とは異なり，畜産排せつ物を発酵せずに炉に入れ水 蒸気とガスを加え, 水素やメタンガスを取り出すため, メ タン発酵と比較して処理時間が短く, その残渣は酸化雾囲 気でさらに熱を加え，分解後に灰分として回収することが できる ${ }^{10)}$.

これより，環境保全と畜産振興との両立が課題となって いる群馬県では, 大学, 高専, 企業, 試験研究機関が共同 し, 家畜排せつ物の低温ガス化・高効率エネルギー変換技 術の開発を進めている ${ }^{11)}$ こここでは, 余剩となっているた い肥を安定的に処理するため, $500{ }^{\circ} \mathrm{C}$ 前後の低温でガス化 し, 生成されたガスをガスエンジンで燃焼し, 電気・熱工 ネルギーを得る方法を検討している，その装置の模式図を Fig. 1 に示す. 得られたエネルギーは温度調整の必要な豚 舎の暖房や，採卵鶏に必要な鶏舎の照明光など，廃棄物処 理と同時に, 畜産農家に必要最低限のエネルギーを供給す ることを計画している，一般に，家畜排せつ物は，他のバ イオマス資源と比較して発熱量が小さいため, 高温でガス 化した場合, 得られるエネルギーが極めて小さくなる，そ のため低温でガス化することができれば効率よくエネル ギーに変換できるものと考えられる.

しかし，低温でガス化するとタール分が多く発生し， タールによって配管の詰まりなどを生じることから, 効率 


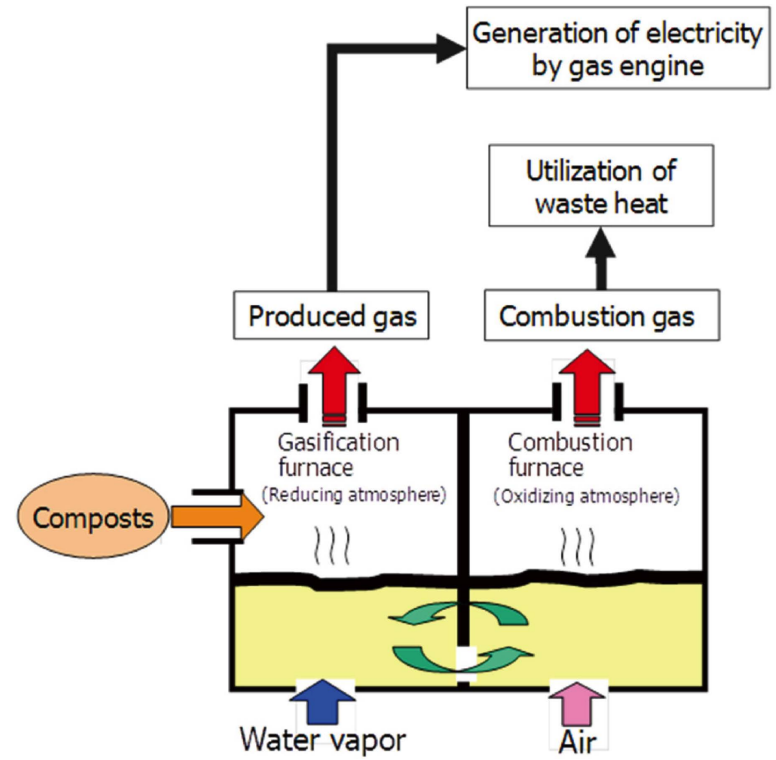

Fig. 1 Schematic illustration of a biomass fluidized bed furnace for livestock manure composts

的なシステム利用が困難になる．特に，タールやガス等に 含まれる硫黄及び塩素化合物がガス化炉内の金属部分に付 着すると, 腐食を引き起こし, 発電効率や装置寿命等の低 下を招く，さらに，家畜排せつ物中の硫黄と塩素は，石炭 などの化石燃料に比べて低いが，それらのガスが排気され ると酸性雨の遠因になることが予想される.

一方, 国内では家畜排せつ物のガス化・エネルギー化に 関する研究と同時に, その過程で発生する副産物を再利用 する動きもあり, 例えば副産物の灰を肥料, 炭化触媒, 脱 硫剂等に転換する試みが行われている ${ }^{12) ~ 14) . ~}$

そこで, 本研究では, 群馬県畜産場から得られた豚筫コ ンポスト（PC）と鶏翼コンポスト（CC）を試料とし, 低 温ガス化プロセスでの物性, 及び熱分解での硫黄及び塩素 のガス，タール，ススへの放出挙動を調べ，さらに，熱分 解後に得られるチャーの再利用への可能性を探索するた め, カルシウムを多く含む CC の熱分解残渣（チャー）を コンポストの熱分解時に放出される硫黄及び塩素の吸着触 媒に応用した結果を報告する。

\section{2 実験}

\section{$2 \cdot 1$ 試 料}

本研究で用いた試料は, 畜産系バイオマスである豚霬コ ンポスト（PC, 林牧場製, 群馬県桐生市) と鶏糞コンポス ト $\left(\mathrm{CC}\right.$, トマル製, 群馬県前橋市) である. 試料は $107{ }^{\circ} \mathrm{C}$ で 1 時間乾燥させたものを粉砕し, 16〜32 メッシュのふるい を使い，0.5 1.0 mm の試料粒径にふるい分けした. 用い た PC と CC の工業分析值と有機元素分析值は依頼分析に より求めた．PCの工業分析値は乾燥重量で揮発分の質
量 $\%$ 濃度が $56 \mathrm{wt} \%$ ，灰分が $27 \mathrm{wt} \%$ ，固定炭素が $17 \mathrm{wt} \%$ であった．また，CCの揮発分は $55.2 \mathrm{wt} \%$ ，灰分は $39 \mathrm{wt} \%$, 固定炭素が $5.9 \mathrm{wt} \%$ であった. 一方, 有機元素分析值から 塩素と硫黄の質量\%濃度は, PC が乾燥重量で $0.95 \mathrm{wt} \%$ と $0.81 \mathrm{wt} \%$, CC が乾燥重量で $1.0 \mathrm{wt} \%$ と $0.68 \mathrm{wt} \%$ であっ た. その他の元素は, PCには乾燥重量で炭素 $52 \mathrm{wt} \%$, 水 素 $6.6 \mathrm{wt} \%$, 窒素 $5.3 \mathrm{wt} \%$, 酸素 $34 \mathrm{wt} \%, \mathrm{CC}$ には炭素 36 wt \%, 水素 $4.1 \mathrm{wt} \%$, 窒素 $3.3 \mathrm{wt} \%$, 酸素 $54 \mathrm{wt} \%$ 含まれて いた.

\section{$2 \cdot 2$ 測 定}

各試料に含まれる化学組成はエネルギー分散型蛍光 X 線 分析装置（EDX: EDX-720, Shimadzu製）を用いた。試料 中のカルシウムの化学形態は X 線回折分析装置 (XRD: Bruker-AXS，Bruker 製）を用いた. EDX 及びXRD の解析 では，乾燥した試料をメノウ乳鉢で細かくすり潰したもの を測定試料とした．また，XRD 測定では，試料板となるガ ラスプレート $(0.2 \mathrm{~mm})$ に充填し, 測定条件は走查間隔を $0.01 \mathrm{deg}$, 走査範囲は $10 \sim 110 \mathrm{deg}$, 走査速度は $2 \mathrm{deg} \mathrm{min}^{-1}$ とした. XRD 測定の出力は $3 \mathrm{~kW}$, 管球は $\mathrm{Cu}(\lambda=1.54 \AA)$ を使用し, 管電圧 $40 \mathrm{kV}$, 電流 $30 \mathrm{~mA}$ であった. コンポス 卜原料, 熱分解後のチャー, ガス, スス, タールに含まれ る硫黄及び塩素の分析には塩素・硫黄分析装置（三菱化学 アナリティック製; NSX2100）を用いた。

また, PC 及び CCを水によって溶出した水溶液中のナト リウム, カリウム及びカルシウムイオンは発光光度分析装 置（日立製作所製，Z-5310），塩化物イオンはサプレッサ付 イオンクロマトグラフ装置（東ソー製，IC-2001）により測 定した.

\section{$2 \cdot 3$ 熱分解実験}

各種廃棄物系バイオマス熱分解時の硫黄と塩素の放出挙 動を調べるため，熱分解実験を行った．実験装置は Fig. 2 に示す固定層二段反応器を用いた。はじめに、コンポスト 試料の熱分解実験では，その試料を石英ウール $0.5 \mathrm{~g}$ に包 んで上段に充填し，還元雲囲気でアルゴン（Ar）ガスを流 量 $120 \mathrm{~mL} \mathrm{~min}{ }^{-1}$ で通気した。 また, 試料の熱分解温度は 500,650 及び $900{ }^{\circ} \mathrm{C}$, 昇温速度は $10^{\circ} \mathrm{C} \mathrm{min}^{-1}$, 保持時間 1 時間で行った，熱分解実験時に発生する夕ールは石英 ウール $1 \mathrm{~g}$ を下段に充填してトラップした．熱分解実験時 に発生する熱分解ガスに含まれる硫黄と塩素は 3 種類の液 体トラップ（各 $30 \mathrm{~mL}$ ）(第 1 トラップ: 脱イオン化した蒸 留水 (以下, 水); 第 2 トラップ: $0.5 \mathrm{~mol} \mathrm{~L}^{-1} \mathrm{NaHCO}_{3}$; 第 3 トラップ: $\left.10 \% \mathrm{H}_{2} \mathrm{O}_{2}\right)$ で回収した後, 水で $50 \mathrm{~mL}$ に定 容した。この試料水に含まれる硫黄及び塩素は塩素・硫黄 分析装置で測定した.

次に, このトラップで回収できなかった硫黄及び塩素 
(a)

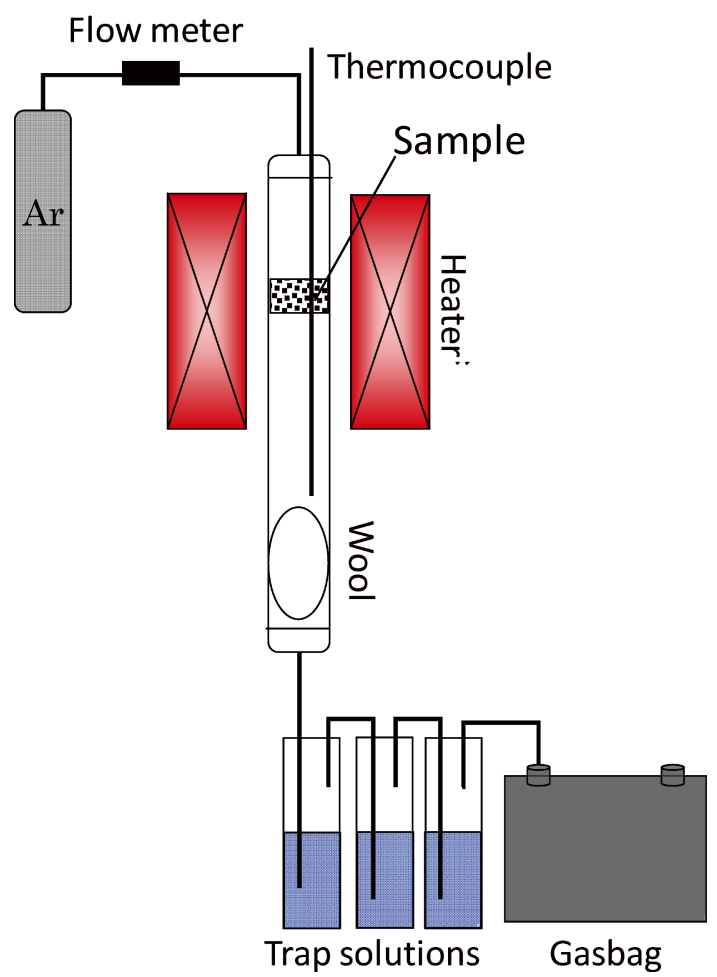

(b)

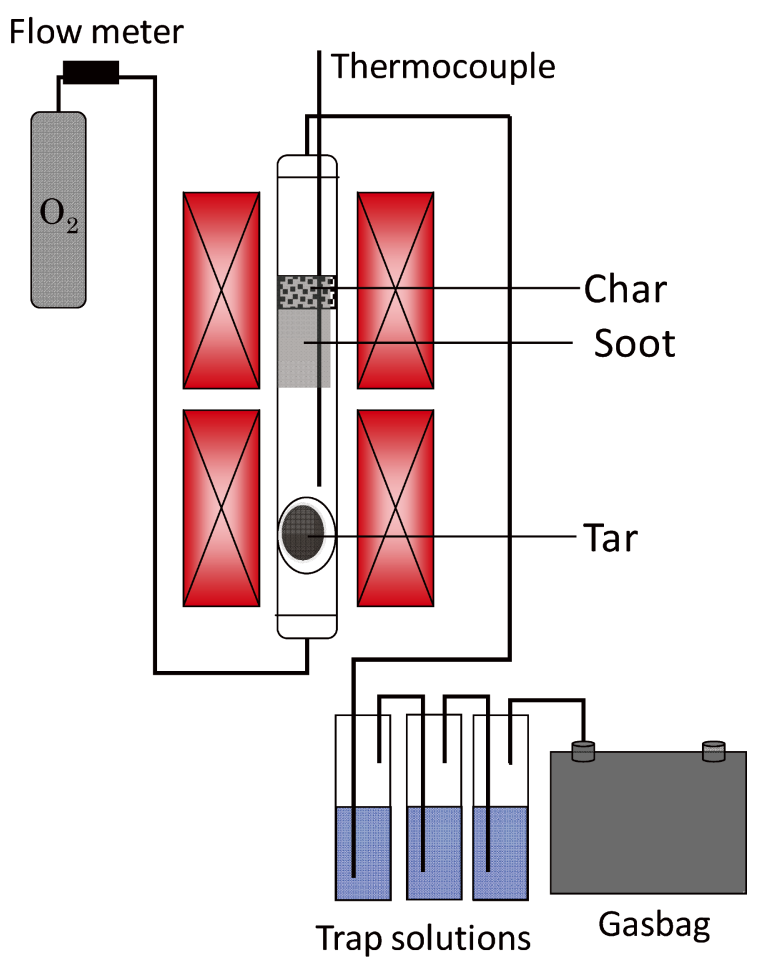

Fig. 2 Schematic illustration of pyrolysis and combustion devises used in this study

Device: (a) pyrolysis of sample under Ar circulation; (b) combustion of residue, soot and tar under $\mathrm{O}_{2}$ circulation.

は，ガス出口で 90 分間，ガスバッグで回収した．ガスバッ クに捕集されたガス濃度は, 検知管式気体測定器（ガス テック製 : model GV100S）を用いて測定した. 検知管の種 類は, 塩素濃度は $\mathrm{HCl}, \mathrm{Cl}_{2}$, 硫黄濃度は $\mathrm{H}_{2} \mathrm{~S}, \mathrm{SO}_{2}$ のガス 検知管を用いて測定した.

\section{$2 \cdot 4$ スス及びタールの分析}

熱分解実験後, 固定層二段反応器（Fig. 2a）の上段には 熱分解残渣であるチャーが残り，チャーのまわりにはスス が発生し，下段には黒い油状液のタールが発生する。 そこ で，スス，タールに含まれる硫黄と塩素を分析するため, はじめに固定層二段反応器の上段（Fig. 2b）を酸素流通下, 流量 $80 \mathrm{~mL} \mathrm{~min}{ }^{-1}$, 燃焼温度 $750{ }^{\circ} \mathrm{C}$ でススを燃焼し, 反応 器の下段を同じ燃焼条件でタールを燃燒した.

スス及びタールを燃焼したときに発生したガスに含まれ る硫黄と塩素は熱分解ガスのトラップと同様に 3 種類の液 体トラップで回収した後, 水で $50 \mathrm{~mL}$ にメスアップした. このサンプルに含まれる硫黄と塩素の測定は $2 \cdot 2$ に記載し たものと同じ装置で行った，液体トラップで回収できな かった硫黄と塩素は, 装置の出口にガスバッグで 1 時間卜 ラップされた．ガスバックに捕集された硫黄と塩素の濃度
は, $2 \cdot 3$ に記載した検知管式気体測定器を用いて測定した.

\section{$2 \cdot 5$ 固体残渣 (チャー) の分析}

熱分解実験後に得られるチャーの試料中に含まれる硫黄 及び塩素は, 各試料 $40 \mathrm{mg}$ に $30 \% \mathrm{HNO}_{3}$ を加え, マイク ロウェーブで分解（分解条件は Power $45 \%$, 圧力 1.17 $\mathrm{MPa}$ ，保持時間 50 分）した後，水で $100 \mathrm{~mL}$ にメスアップ し，塩素・硫黄分析装置により測定した。

\section{2・6 CC チャーの脱硫・脱塩効果}

PC熱分解時に発生した硫黄及び塩素に対するCCチャー の吸着効果を調べるため, Fig. 3 のように, 固定層二段反 応器の石英反応管に設置した触媒層に CC チャーを $1 \mathrm{~g}$ 充 填し，その試料層に PC $1.0 \mathrm{~g}$ を石英ウール $0.5 \mathrm{~g}$ に包んで 充填した. 熱分解条件は還元䨌囲気 (Ar ガス流通) で流量： $120 \mathrm{~mL} \mathrm{~min}^{-1}$, 熱分解温度 $500,650,900{ }^{\circ} \mathrm{C}$ で昇温速度： $10{ }^{\circ} \mathrm{C} \min ^{-1}$, 保持時間 1 時間で行った. 熱分解実験時に発 生するタールは石英ウール $1 \mathrm{~g}$ を触媒層の下に充填してト ラップした，石英ウールにトラップされたタール，試料層 及び触媒層周辺のススの分析は $2 \cdot 4$ 項と同様であった. 


\section{3 結果及び考察}

\section{$3 \cdot 1$ 低温熱分解による家畜排せつ物試料の物性変化}

$3 \cdot 1 \cdot 1$ 豚糞コンポスト (PC) はじめに, 熱分解前の $\mathrm{PC}$ 試料及び $500,650,900{ }^{\circ} \mathrm{C}$ で熱分解した後の $\mathrm{PC}$ チャー 中に含まれる元素組成を調べるため, EDX 分析を行った. その結果, Table 1 に示されるように, 熱分解前及び 500 , $650,900{ }^{\circ} \mathrm{C}$ で熱分解後のチャーのいずれにおいても，カ ルシウムの割合が 50 \% 前後と最も多く含まれており，次 にカリウム，リン，鉄の順で含まれていた。これょり，PC

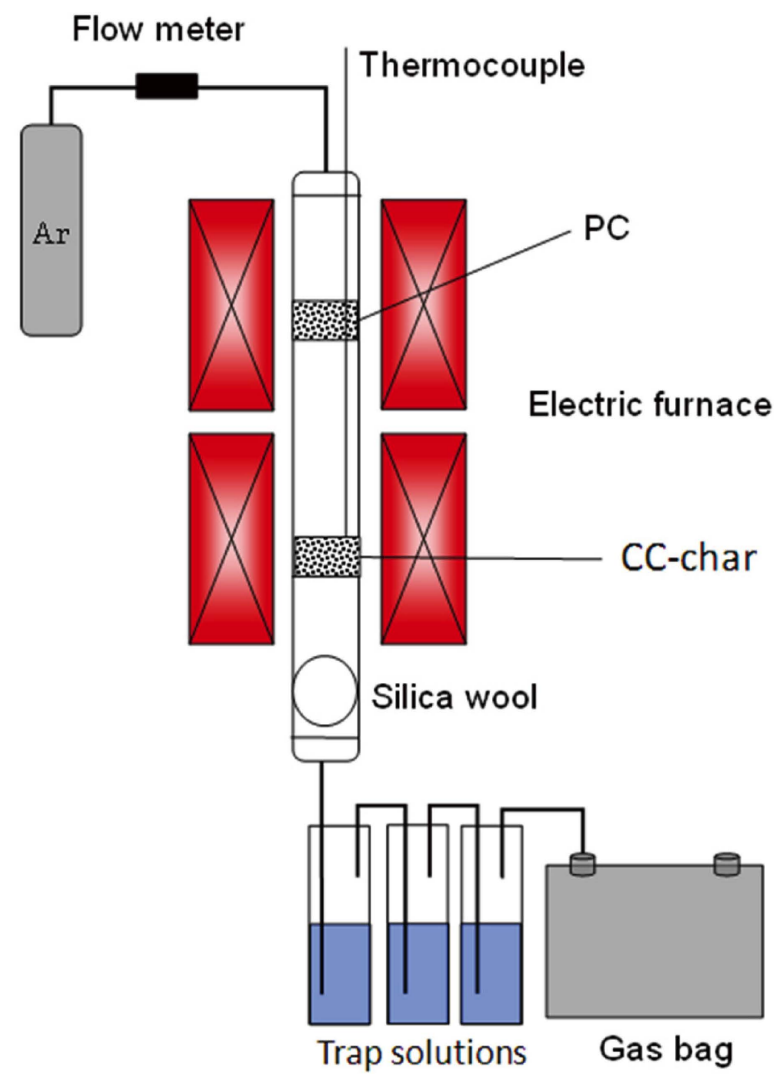

Fig. 3 Schematic illustrations of the gasification furnace system with CC-char as an adsorbent for chlorine and sulfur
原料の主成分であるカルシウム及びリンは，養豚に与える 配合飼料に骨の栄養素として石灰石を粉砕した $\mathrm{CaCO}_{3}$ や 天然鉱石から製造されたリン酸カルシウムを原料として加 えているためであると予想される ${ }^{15)}$. また，カリウム及び 鉄は家畜の体内機能の維持や調節を行う必須元素が排出さ れたためと考えられる，その他の成分として硫黄，亜鉛， ケイ素が存在しており, マンガンと銅は $1 \%$ 未満であっ た。また，熱分解後の PC チャーの硫黄の割合は他の元素 とは異なり, 熱分解前の PC と比較して低くなっているこ とが分かった。

次に, 熱分解前後のPC チャーの結晶構造の変化を調べ るため，XRDを用いて解析した。 その結果， Fig. 4a に示 されるように, PC は XRD 分析結果から $15^{\circ}$ 付近にブロー ドのピークが検出された。これは $\mathrm{PC}$ の構造がアモルファ スであるためだと考えられる。ささらに，PCを熱分解する (a)

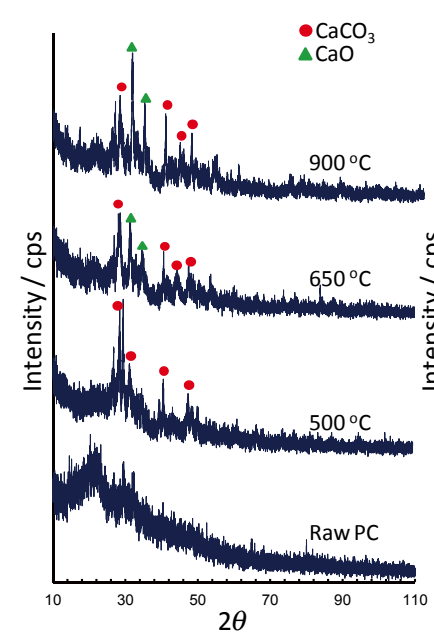

(b)

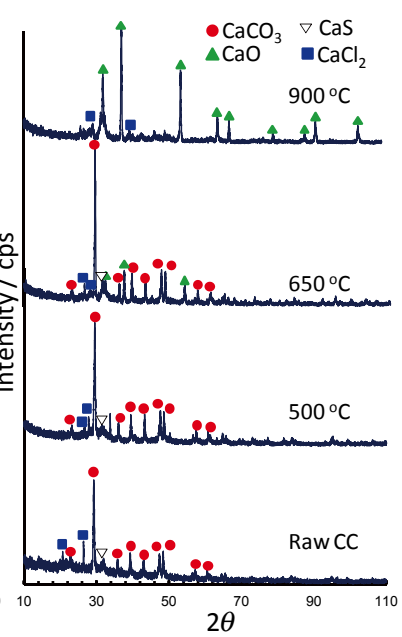

Fig. 4 XRD patterns of compost samples and the chars obtained after each pyrolysis at different temperatures

Samples: (a) PC and the chars; and (b) CC and the chars.

Table 1 EDX analysis of raw compost samples and the chars on each pyrolysis temperature

\begin{tabular}{|c|c|c|c|c|c|c|c|c|}
\hline & \multirow{2}{*}{ Raw PC, \% } & \multicolumn{3}{|c|}{ PC char, \% } & \multirow{2}{*}{ Raw CC, \% } & \multicolumn{3}{|c|}{ CC char, \% } \\
\hline & & $500{ }^{\circ} \mathrm{C}$ & $650{ }^{\circ} \mathrm{C}$ & $900{ }^{\circ} \mathrm{C}$ & & $500{ }^{\circ} \mathrm{C}$ & $650{ }^{\circ} \mathrm{C}$ & $900{ }^{\circ} \mathrm{C}$ \\
\hline $\mathrm{Ca}$ & 50.7 & 49.5 & 50.8 & 49.8 & 69.3 & 70.9 & 72.1 & 72.3 \\
\hline K & 13.9 & 16.0 & 15.0 & 15.4 & 11.2 & 11.3 & 9.3 & 8.9 \\
\hline $\mathrm{P}$ & 12.9 & 13.0 & 13.2 & 13.3 & 7.6 & 7.2 & 7.3 & 7.7 \\
\hline $\mathrm{Fe}$ & 9.8 & 9.3 & 9.1 & 10.0 & 2.4 & 2.7 & 2.3 & 2.4 \\
\hline $\mathrm{S}$ & 6.2 & 2.2 & 2.4 & 2.1 & 6.2 & 3.3 & 2.9 & 2.1 \\
\hline Zn & 2.7 & 2.8 & 2.5 & 1.9 & 0.3 & 0.2 & 0.2 & 0.1 \\
\hline $\mathrm{Si}$ & 5.3 & 5.6 & 5.9 & 6.1 & 3.2 & 2.9 & 3.2 & 3.5 \\
\hline $\mathrm{Mn}$ & 0.5 & 0.6 & 0.5 & 0.5 & 0.2 & 0.3 & 0.2 & 0.2 \\
\hline $\mathrm{Cu}$ & 0.4 & 0.4 & 0.5 & 0.3 & 0.2 & 0.2 & 0.2 & 0.1 \\
\hline
\end{tabular}


(a)

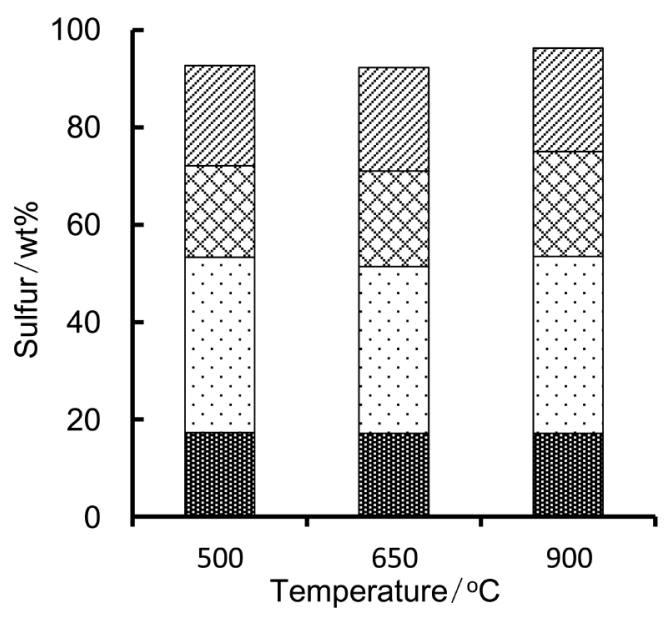

(b)

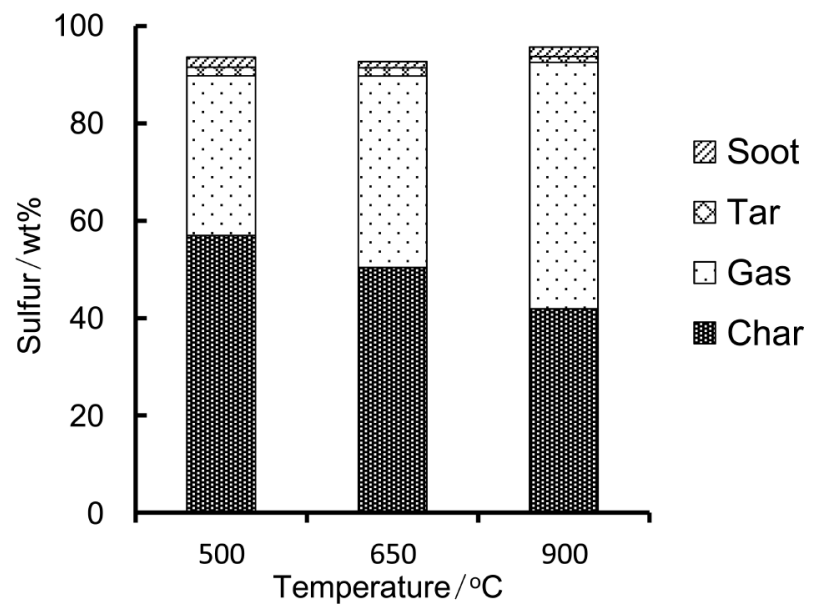

Fig. 5 Distribution of sulfur content in PC and CC before and after pyrolysis Bar graphs: (a) PC; and (b) CC.

と, $30^{\circ}$ から $40^{\circ}$ の間にピークが確認され, 熱分解温度に依 存して増加することが分かった。 これらは $\mathrm{CaCO}_{3}$ と $\mathrm{CaO}$ 由来のものと考えられ, 熱分解に伴い, それらの結晶化度 が上昇したものと考えられる。

$\mathbf{3} \cdot \mathbf{1} \cdot \mathbf{2}$ 䳕糞コンポスト $(\mathrm{CC})$ 次に, $\mathrm{CC}$ の元素組成 について, PC と同様に EDX 分析を行った結果を Table 1 に示す. 熱分解前の CC 及び熱分解後のチャー中には, PC と同様にカルシウムが $70 \sim 80 \%$ となり, PCよりもカル シウムの割合が高いことが分かった。 これは, 養豚と同様 に養䳕に与える配合飼料に炭酸カルシウムを原料として加 えており,さらに採卵する鶏用飼料には卵款を強くするた めに炭酸カルシウムを加える量も $40 \mathrm{wt} \%$ と比較的高いた めであると考えられる ${ }^{15)}$. また, カリウムは体内機能の維 持や調節を行う必須元素であり, 配合飼料からカルシウム を摂取するため, その一部が鶏糞として排出されたものと 考えられる. なお, $\mathrm{CC}$ も $\mathrm{PC}$ と同様に, 熱分解後の $\mathrm{CC}$ チャーの硫黄の割合が熱分解前の CC と比べ減少する傾向 にあり，硫黄は熱分解によって容易に放出されることが考 えられる。

次に, CC中の熱分解温度 $500,650,900{ }^{\circ} \mathrm{C}$ の CCチャー 中の金属形態を調べるためにXRD を用いて分析した結果,

Fig. $4 \mathrm{~b}$ に示されるように, CC 原料中にはカルシウムが大 部分を占めており, その形態は主に $\mathrm{CaCO}_{3}$ として存在して いた。

熱分解温度 $500{ }^{\circ} \mathrm{C}$ の CC チャーのカルシウムは CC 原料 由来の $\mathrm{CaCO}_{3}$ が存在していたが, 熱分解温度 $650{ }^{\circ} \mathrm{C}$ では $\mathrm{CaCO}_{3}$ から $\mathrm{CaO}$ への変化が見られた. 熱分解温度 $900{ }^{\circ} \mathrm{C}$ の CGチャーではカルシウムのほとんどが $\mathrm{CaO}$ に変換され ていた. 加えて, 原料の CC, 熱分解した後のチャーのXRD パターンには, $\mathrm{CaS}$ や $\mathrm{CaCl}_{2}$ のピークが確認できた.

\section{$3 \cdot 2$ 熱分解による硫黄と塩素の放出挙動}

3・2・1 硫黄（S） はじめに, PC を熱分解した後の硫 黄の収支を Fig. $5 \mathrm{a}$ に示す. 物質収支は PC 原料中の硫黄含 有量 $\left(34.0 \mathrm{mmol} \mathrm{g}^{-1}\right)$ に対し, 熱分解後のチャー, ガス, タール及びススに含まれる硫黄含有量から式 (1)を用い て算出された。これより, 熱分解温度を上昇させても チャー, ガス, タール, ススに含まれる硫黄の濃度に変化 が見られず， $500{ }^{\circ} \mathrm{C}$ の熱分解では，チャー中に残る硫黄が $17 \mathrm{wt} \%$ で, ガス, タール，ススに放出される硫黄が 35 wt\%, $19 \mathrm{wt} \%, 21 \mathrm{wt} \%$ であった. また, PCからガス, タール，ススに放出された割合 [式( 1 ) ] は $82 \%$ となっ た.さらに, 熱分解温度を上げても, 放出された硫黄の割 合は $650{ }^{\circ} \mathrm{C}$ で $81 \%, 900{ }^{\circ} \mathrm{C}$ で $82 \%$ となり, ガス, ター ル, ススに含まれる硫黄の割合も500 ㄷで結果とほとん ど同じであった.

$$
A_{r}(\%)=\frac{[\mathrm{A}]_{\mathrm{g}, \mathrm{ts}}}{[\mathrm{A}]_{\mathrm{all}}} \times 100
$$

$A_{r}$ : 対象元素の放出割合; $[\mathrm{A}]_{\mathrm{all}}$ : チャー, ガス, タール, ススに含まれる対象元素の濃度の合計 ; $[\mathrm{A}]_{\mathrm{g}, \mathrm{t,s}}$ : ガス, ター ル，ススに含まれる対象元素の濃度の合計.

これより, 熱分解温度 $500{ }^{\circ} \mathrm{C}$ においてもチャーに残留す る硫黄は低いため, PC 原料中の硫黄の化学形態は熱分解 温度 $500{ }^{\circ} \mathrm{C}$ 以下の硫黄化合物が比較的高い割合で含まれ ているものと予想される.

一方，各熱分解温度における CC（硫黄濃度: 27.2 $\mathrm{mmol} \mathrm{g}^{-1}$ ) を熱分解した後の硫黄の収支は, Fig. $5 \mathrm{~b}$ に示

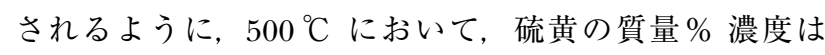
チャー $57 \mathrm{wt} \%$, 生成ガス $33 \mathrm{wt} \%$, タールは $2.1 \mathrm{wt} \%$, ス 
(a)

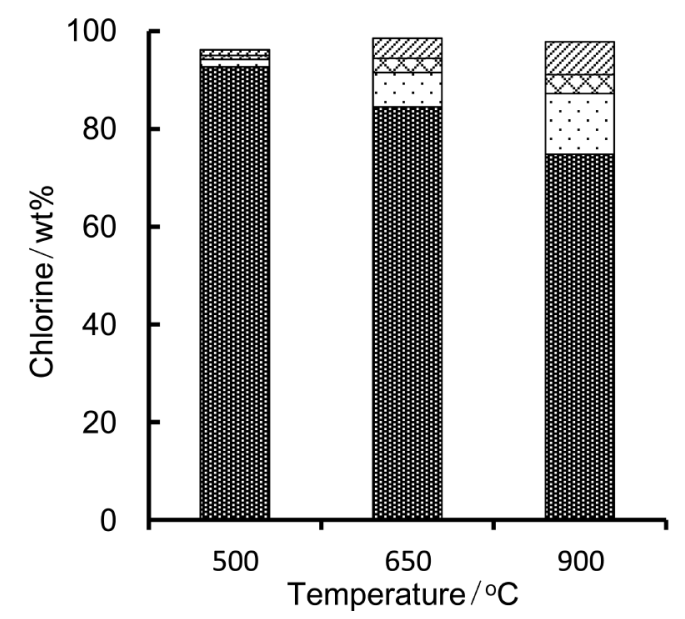

(b)

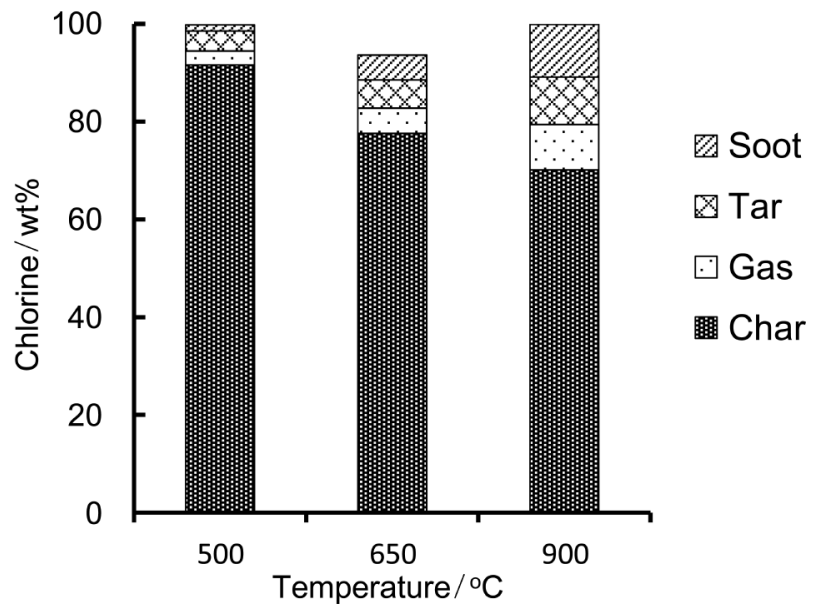

Fig. 6 Distribution of chlorine content in PC and CC before and after pyrolysis Bar graphs: (a) PC; and (b) CG.

Table 2 Possible sources of sulfur and chlorine ${ }^{16)}$

\begin{tabular}{llc}
\hline & Species (main component) & $\begin{array}{c}\text { Decomposition } \\
\text { temp, }{ }^{\circ} \mathrm{C}\end{array}$ \\
\hline Sulfur & Pyrite $\left(\mathrm{FeS}_{2}\right)$ & $550-1200$ \\
& Gypsum $\left(\mathrm{CaSO}_{4} \cdot 2 \mathrm{H}_{2} \mathrm{O}\right)$ & 1200 \\
& $\begin{array}{l}\text { Organic matter }(\mathrm{cysteine}, \\
\text { methionine, etc. }\end{array}$ & $300-500$ \\
Chlorine & Chlorapatite $\left(\mathrm{Ca}_{5}\left(\mathrm{PO}_{4}\right)_{3} \mathrm{Cl}\right)$ & $450-750$ \\
& Halite $(\mathrm{NaCl})$ & 800 \\
\hline
\end{tabular}

スは $2.0 \mathrm{wt} \%, 650{ }^{\circ} \mathrm{C}$ においては, チャー $50 \mathrm{wt} \%$, ガス $39 \mathrm{wt} \%$, タール $2.0 \mathrm{wt} \%$, スス $0.98 \mathrm{wt} \%, 900{ }^{\circ} \mathrm{C}$ におい てチャー $42 \mathrm{wt} \%$, ガス $51 \mathrm{wt} \%$, タール $1.1 \mathrm{wt} \%$, スス 1.7 wt\%であった.

これより, CC から放出された硫黄の割合が, $500{ }^{\circ} \mathrm{C}$ で $39 \%, 650{ }^{\circ} \mathrm{C}$ で $46 \%, 900{ }^{\circ} \mathrm{C}$ で $56 \%$ となり, 熱分解温 度に依存して, 硫黄が放出されやすくなることが分かっ た.また, CCに含まれる硫黄化合物は, $500 〜 900{ }^{\circ} \mathrm{C}$ で分 解するものが, $\mathrm{PC}$ よも多く含まれているものと予想さ れる.

$3 \cdot 2 \cdot 2$ 塩素 $(\mathrm{Cl})$ 次に, 各熱分解温度における $\mathrm{PC}$ の熱分解後の塩素の収支を Fig. 6a に示す. このときの PC 原料中の塩素濃度は $20.9 \mathrm{mmol} \mathrm{g}^{-1}$ であった. Fig. 6aより, 塩素の大部分は PC を熱分解したチャーに残留しているこ とが分かる. 熱分解温度 $500{ }^{\circ} \mathrm{C}$ では, チャーに残留した塩 素は $93 \mathrm{wt} \%$ で, ガス, タール, ススとして放出した塩素 は $2.3 \mathrm{wt} \%, 0.81 \mathrm{wt} \%, 1.2 \mathrm{wt} \%$ であり, 式 $(1)$ より算出 した塩素の放出割合は $3.6 \%$ であった。 また, 熱分解温度
$650{ }^{\circ} \mathrm{C}$ での放出割合は $14 \%, 900{ }^{\circ} \mathrm{C}$ では $24 \%$ と熱分解 温度の上昇に伴い増加傾向であるものの, 硫黄と比較して 放出される割合は低いことが分かった.

一方, 各熱分解温度における CC（塩素濃度: 20.5 $\mathrm{mmol} \mathrm{g}^{-1}$ ) の熱分解実験後の塩素の収支は, Fig. $6 \mathrm{~b}$ に示 されるように, PC と同様に大部分はチャーに残留してい ることが分かった. 熱分解温度 $500{ }^{\circ} \mathrm{C}$ においてチャーに残 留した塩素は $92 \mathrm{wt} \%$ と, ガス, タール，ススとして放出 される割合が小さく，それぞれ $2.8 \mathrm{wt} \%, 3.7 \mathrm{wt} \%, 1.1 \mathrm{wt} \%$ であった（放出割合： $8 \%$ )。また, 熱分解温度 $650{ }^{\circ} \mathrm{C}$ での 放出割合は $17 \%, 900{ }^{\circ} \mathrm{C}$ では $30 \%$ と, PCで得られた結 果とほぼ同様の傾向を示した。これより, 熱分解温度 $900{ }^{\circ} \mathrm{C}$ でも塩素の多くはチャーに残留していたため, CC 中の塩素の化学形態の多くは熱分解温度 $900{ }^{\circ} \mathrm{C}$ 以上の塩 素化合物が含まれているものと予想される.

なお, 本研究では, PC 及び CCに含まれる主要成分であ るリン, 鉄, 銅, 亜鉛の放出挙動についても検討したが, 熱分解温度に関係なく, 放出割合はいずれも $1 \%$ 以下であ り，ほとんどがチャーに留まることが分かった。

\section{$3 \cdot 3$ 硫黄及び塩素の放出源}

これまで $\mathrm{PC}$ 及び CC の熱分解時での硫黄及び塩素の放 出挙動について述べたが, 次にこれらの放出源となる化学 形態について考察した. なお, Table 2 は参考として硫黄化 合物及び塩素化合物の分解温度をまとめた ${ }^{16)}$.

3・3・1 硫黄 $(\mathrm{S}) \quad \mathrm{PC}$ では, 熱分解温度によって チャーに残留する硫黄の含有量に大きな違いはなく, $500{ }^{\circ} \mathrm{C}$ で $17 \mathrm{wt} \%, 650{ }^{\circ} \mathrm{C}$ で $17 \mathrm{wt} \%, 900{ }^{\circ} \mathrm{C}$ で $16 \mathrm{wt} \%$ で あった.したがって, PC 原料中の硫黄化合物の多くは, 熱 
分解温度が $500{ }^{\circ} \mathrm{C}$ よりも低く, 放出されやすい形態で存在 しているものと予想される．例えば，硫黄化合物の中で分 解温度 $500{ }^{\circ} \mathrm{C}$ よりも低く放出されやすい硫黄化合物とし ては有機硫黄が考えられる ${ }^{16)}$. 豚翼や鷄貨などの畜産廃棄 物には硫黄元素を含むメチオニンやシステイン等の硫黄を 含むアミノ酸が含まれて打り，それらのアミノ酸を残基と するタンパク質も含まれているとされる ${ }^{16) 17)}$ ．また，本研 究での熱分解実験において, $500 \sim 900{ }^{\circ} \mathrm{C}$ で得られた チャー中に残留する硫黄量に大きな変化が見られなかった ため, PC 原料中の一部は $900{ }^{\circ} \mathrm{C}$ 以上で分解する硫黄化合 物，例えば $\mathrm{CaSO}_{4}$ が含まれていると考えられる.

一方， CCでは，熱分解後にチャーに残留する硫黄の質 量\% 濃度は, $500{ }^{\circ} \mathrm{C}$ で $57 \mathrm{wt} \%, 650{ }^{\circ} \mathrm{C}$ で $50 \mathrm{wt} \%, 900{ }^{\circ} \mathrm{C}$ で $42 \mathrm{wt} \%$ であった。これは PCよりも CC中に分解温度の 高い硫黄化合物が多く含まれ抢り, PC と同様に CC も硫黄 を含むタンパク質やアミノ酸が硫黄の放出源の一部となっ ている可能性も考えられる，ただし，具体的な化合物を突 き止めるには, 多種多様な化合物が考えられ，現段階では 困難であった。

$3 \cdot 3 \cdot 2$ 塩素 $(\mathrm{Cl}) \quad \mathrm{PC}$ 及び $\mathrm{CC}$ の塩素の放出挙動を考 えたとき，いずれの試料中の塩素も熱分解温度 500〜 $900{ }^{\circ} \mathrm{C}$ において, チャーに残留する塩素の割合が高かった ことから, 分解温度 $900{ }^{\circ} \mathrm{C}$ 以上の塩素化合物が多く存在し ていると予想される. Gonzalez らの報告では, $\mathrm{NaCl}, \mathrm{KCl}$ 及び $\mathrm{CaCl}_{2}$ の沸点がそれぞれ 800,772 及び $782{ }^{\circ} \mathrm{C}$ である ことから，アルカリ塩化物が原料中に含まれている可能性 がある ${ }^{16)}$.

これらの存在を確認するため, 本研究では $\mathrm{PC}$ 及び $\mathrm{CC} の$ 乾燥試料 $1 \mathrm{~g}$ を $50 \mathrm{~mL}$ の水で 1 時間擋挷し, 吸引汇過して この沪液を水で $100 \mathrm{~mL}$ に定容し，これらの試料に含まれ る塩化物イオン濃度を定量することで, 試料中の塩素がど れだけ水に溶解するかを確認した，その結果，PC 及び CC 中の塩素はそれぞれ $97 \mathrm{wt} \%$ 及び $95 \mathrm{wt} \%$ 溶解することが 分かった。

これより, 原料中の塩素化合物は $\mathrm{NaCl}$ (溶解度 : $35.9 \mathrm{~g}$ / $100 \mathrm{~g}$ of water $)^{16)}$ のような溶解度の高いアルカリ塩化物で あると予測される。これは，養豚や養䳕に与えられる飼料 には食塩を配合していることが関係している可能性が高 い.

$\mathrm{KCl}$ の存在については, $\mathrm{PC}$ 及び CC のいずれも EDX 分 析の結果から, カルシウムに次いでカリウムが多く存在し て打り, $\mathrm{KCl}$ の溶解度（溶解度 : $31.2 \mathrm{~g} / 100 \mathrm{~g}$ of water）は $\mathrm{NaCl}$ に近い. Wei $ら^{17)}$ は一般廃棄物固形燃料 (RDF) と石 炭を混合燃焼したとき, $\mathrm{NaCl}$ ガス, $\mathrm{KCl}$ ガスは $900 \mathrm{~K}$ $\left(627{ }^{\circ} \mathrm{C}\right)$ で放出し始めると報告している. また, Kuramochi $ら^{18)}$ はバイオマスの固体試料中での $\mathrm{KCl}$ の形成が $\mathrm{HCl}$ 排出 量の低下につながることを報告している，したがって，原
料中のアルカリ塩化物は $\mathrm{NaCl}$ と共に $\mathrm{KCl}$ も存在している 可能性が考えられ，これらが塩素の放出量に影響している ものと推察される.

また, $\mathrm{CC} に は \mathrm{XRD}$ 分析から $\mathrm{CaCl}_{2}$ のピークが確認でき， その溶解度 $\left(81.5 \mathrm{~g} / 100 \mathrm{~g}\right.$ of water) も高いことから $\mathrm{CaCl}_{2}$ の存在も考えられる. Fraissler ${ }^{199}$ は $\mathrm{CaCl}_{2}$ が分解する温 度は $782{ }^{\circ} \mathrm{C}, \mathrm{NaCl}$ は $800{ }^{\circ} \mathrm{C}, \mathrm{KCl}$ は $772{ }^{\circ} \mathrm{C}$ と, 比較的分 解温度が高いことを報告している，さらに，本研究では， $\mathrm{PC}$ 及びCCを水によって溶出した水溶液中のナトリウムイ オン, カリウムイオン, カルシウムイオンを発光光度分析 法, 塩化物イオンをイオンクロマトグラフィーで測定した ところ, PCのナトリウムイオン, カリウムイオン, カルシウ ムイオン及び塩化物イオンの濃度はそれぞれ $20.4 \mathrm{mmol} \mathrm{g}^{-1}$, $46.4 \mathrm{mmol} \mathrm{g}^{-1}, 0.5 \mathrm{mmol} \mathrm{g}^{-1}$ 及び $20.1 \mathrm{mmol} \mathrm{g}^{-1}$, 一方, CCはそれぞれ $23.4 \mathrm{mmol} \mathrm{g}^{-1}, 57.7 \mathrm{mmol} \mathrm{g}^{-1}, 1.9 \mathrm{mmol} \mathrm{g}^{-1}$ 及び $20.3 \mathrm{mmol} \mathrm{g}^{-1}$ となり, PC と CC の間に大きな差は見 られなかった．したがって，PC 及び CCの塩素の主な放出 源としては $\mathrm{NaCl}, \mathrm{KCl}$ に加え $\mathrm{CaCl}_{2}$ も含まれていると考え られる。

\section{$3 \cdot 4$ CC チャーの脱硫・脱塩効果}

次に, カルシウムが多く含まれている CCチャーを，家 畜排せつ物の熱分解によって放出される硫黄及び塩素の吸 着触媒としての機能を評価するため, 固定層二段反応器 （Fig. 3）の触媒層に CC チャーを充填したときの硫黄と塩 素の物質収支を調べた。この実験は，バイオマスガスの生 成をガス化するときに発生する硫黄と塩素の吸着剤とし て, カルシウムを含む化合物 $\left(\mathrm{CaCO}_{3}, \mathrm{Ca}(\mathrm{OH})_{2}\right.$ 等 $)$ を用 いることに関連している200 24).これより，カルシウムを多 く含む CCチャーが脱硫・脱塩効果を示すことができれ ば，熱分解後の固体残渣の再利用対策に繁がるものと期待 できる.

CCチャーによるPCの熱分解時の硫黄と塩素の放出挙動 の分析結果を Fig. 7 に示す。図中にある「None」と $\lceil\mathrm{CC}-\mathrm{char} 」$ は，固定層二段反応器の触媒層にそれぞれ「CC チャーを充填しなかったとき」と「CCチャーを充填した とき」を意味する，また，CCチャーに保持された硫黄 · 塩素の質量\% 濃度は, 熱分解後の CC チャー中の硫黄・塩 素量から熱分解前の CC チャー中のそれらを差し引いた值 を示す.

なお，本実験のブランクとして，触媒層に充填した $\mathrm{CC}$ チャーのみを熱分解したとき，いずれの熱分解温度でもス

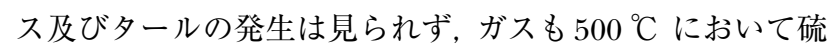
黄及び塩素が共に $0.1 \mathrm{wt} \%$ 未満であった。

3·4・1 硫黄 $(\mathbf{S})$ はじめに, CCチャー存在下におけ る PC 熱分解時での硫黄の物質収支を Fig. 7a に示す.これ より，PCを熱分解した場合では，CCチャーに吸着した硫黄 
(a)

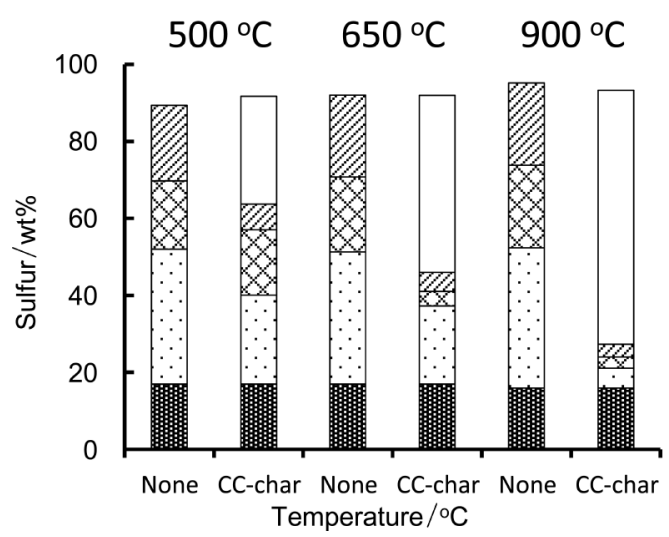

(b)

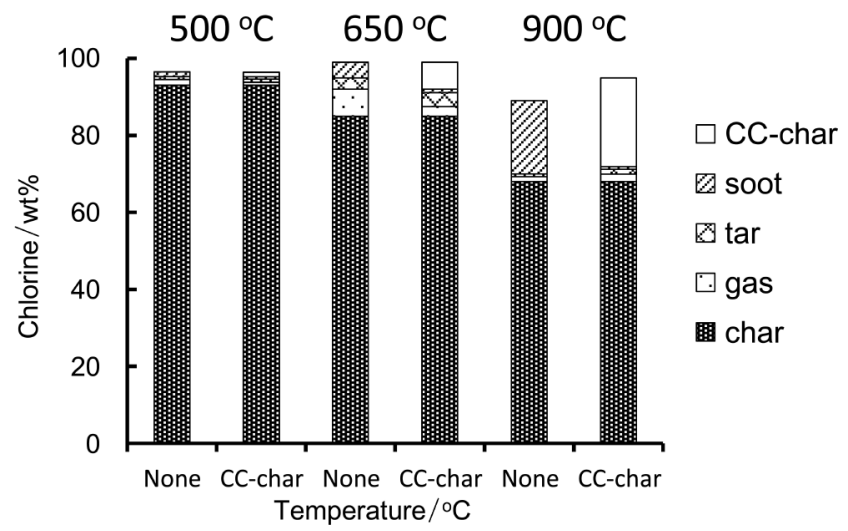

Fig. 7 Distributions of sulfur (a) and chlorine (b) in pyrolysis with CC char

量は熱分解温度 $500{ }^{\circ} \mathrm{C}: 24 \mathrm{wt} \%, 650{ }^{\circ} \mathrm{C}: 43 \mathrm{wt} \%, 900{ }^{\circ} \mathrm{C}$ : $63 \mathrm{wt} \%$ となり, 熱分解温度に依存して増加した.

この結果を基に, CCチャーの存在下での PCの熱分解に おける生成ガスからの脱硫率を式 ( 2 ) より算出した.

$$
\text { 脱硫率 }(\%)=\left(1-\frac{[\mathrm{S}]_{\mathrm{g}}}{[\mathrm{S}]_{0}}\right) \times 100
$$

ここで, $[\mathrm{S}]_{0}$ は CCチャーが触媒層に充填されていないと きにPC放出されるガス中の硫黄量 $(\%),[\mathrm{S}]_{\mathrm{g}}$ は CCチャー 存在下でのガス中の硫黄量（\%）を示す.

これより, 熱分解温度 $500{ }^{\circ} \mathrm{C}$ で CC チャーによる生成ガ スからの脱硫率は $34 \%, 650{ }^{\circ} \mathrm{C}$ では $41 \%, 900{ }^{\circ} \mathrm{C}$ では $86 \%$ となった. また, 式（1） と同様の算出方法により, ススからの脱硫率は熱分解温度 $500{ }^{\circ} \mathrm{C}, 650{ }^{\circ} \mathrm{C}, 900{ }^{\circ} \mathrm{C}$ の 順で $66 \%, 77 \%, 85 \%$, タールの脱硫率は熱分解温度 $500{ }^{\circ} \mathrm{C}, 650{ }^{\circ} \mathrm{C}, 900{ }^{\circ} \mathrm{C}$ の順で $4.5 \%, 80 \%, 87 \%$ となっ た.したがって, 熱分解温度 $500{ }^{\circ} \mathrm{C}$ での $\mathrm{CC}$ チャーの脱硫 効率がタールに対して極端に低い結果となった。

$\mathbf{3 \cdot 4 ・ 2}$ 塩素 $(\mathrm{Cl})$ 熱分解温度が $500{ }^{\circ} \mathrm{C}$ のときは, PC からの塩素の放出がほとんど見られず，吸着剤として用い た CCチャーへの塩素の吸着量は $1.2 \mathrm{wt} \%$ と低い值となっ た. また, 熱分解温度が $650{ }^{\circ} \mathrm{C}$ と $900{ }^{\circ} \mathrm{C}$ のときの CC チャーへの塩素の吸着量は, それぞれ $7.0 \mathrm{wt} \%$ と $19.0 \mathrm{wt} \%$ となり, 熱分解温度が上昇し, PCから放出されるガス, タール, ススの割合が増加するにしたがって，CCチャー へ吸着される塩素量も増加することが分かった。

この結果を基に, CCチャーの存在下での PCの熱分解に おける生成ガスからの脱塩率を式 ( 3 ) より算出した.
脱塩率 $(\%)=\left(1-\frac{[\mathrm{Cl}]_{\mathrm{g}}}{[\mathrm{Cl}]_{0}}\right) \times 100$

ここで, $[\mathrm{Cl}]_{0}$ は $\mathrm{CC}$ チャーが触媒層に充填されていないと きに $\mathrm{PC}$ から放出されるガス中の塩素量 $(\%),[\mathrm{Cl}]_{\mathrm{g}}$ は CC チャー存在下でのガス中の塩素量（\%) を示す.

これより, 熱分解温度 $500{ }^{\circ} \mathrm{C}$ で CC チャーによる生成ガ スからの脱塩率は $47 \%, 650{ }^{\circ} \mathrm{C}$ では $64 \%, 900{ }^{\circ} \mathrm{C}$ では $85 \%$ となった. また, 式 (3) と同様の算出方法により, ススからの脱塩率は熱分解温度 $500{ }^{\circ} \mathrm{C}, 650{ }^{\circ} \mathrm{C}, 900{ }^{\circ} \mathrm{C}$ の 順で $50 \%, 78 \%, 87 \%$, タールの脱塩率は熱分解温度 $500{ }^{\circ} \mathrm{C}, 650{ }^{\circ} \mathrm{C}, 900{ }^{\circ} \mathrm{C}$ の順で $0 \%, 24 \%, 67 \%$ となり, ここでも, 熱分解温度 $500{ }^{\circ} \mathrm{C}$ において, タールからの脱塩 効果がほとんど示されないことが分かった.

以上より, 触媒層に充填された CCチャーの硫黄と塩素 に対する吸着能はほぼ同程度であった。 熱分解温度 $500{ }^{\circ} \mathrm{C}$ において PC 及び CC から生成したタールからの脱硫率・ 脱塩率が低い理由については, タールそのものの物性や硫 黄及び塩素の化学形態が関与しているものと予想される.

3・4・3 CC チャー中のカルシウムの化学形態変化 上述したように，CCチャーが固定層二段反応器の触媒層 に充填されたとき，家畜排せつ物から放出される硫黄，塩 素の吸着剤として機能することが示され, その吸着サイト として, CCチャーに多く含まれるカルシウムが関与して いるものと考えられる.

そこで, PCを $500{ }^{\circ} \mathrm{C}, 650{ }^{\circ} \mathrm{C}, 900{ }^{\circ} \mathrm{C}$ で熱分解し生成し たガス, スス, タールの硫黄と塩素が, 触媒層の CCチャー に吸着したときのカルシウムの化学形態をXRDによって 調べた.その結果を Fig. 8 に示し, 比較として CCを $500{ }^{\circ} \mathrm{C}, \quad 650{ }^{\circ} \mathrm{C}, 900{ }^{\circ} \mathrm{C}$ で熱分解したときの CCチャーの XRD パターンも併せて示す (Fig. $4 \mathrm{~b}$ と同じ). 

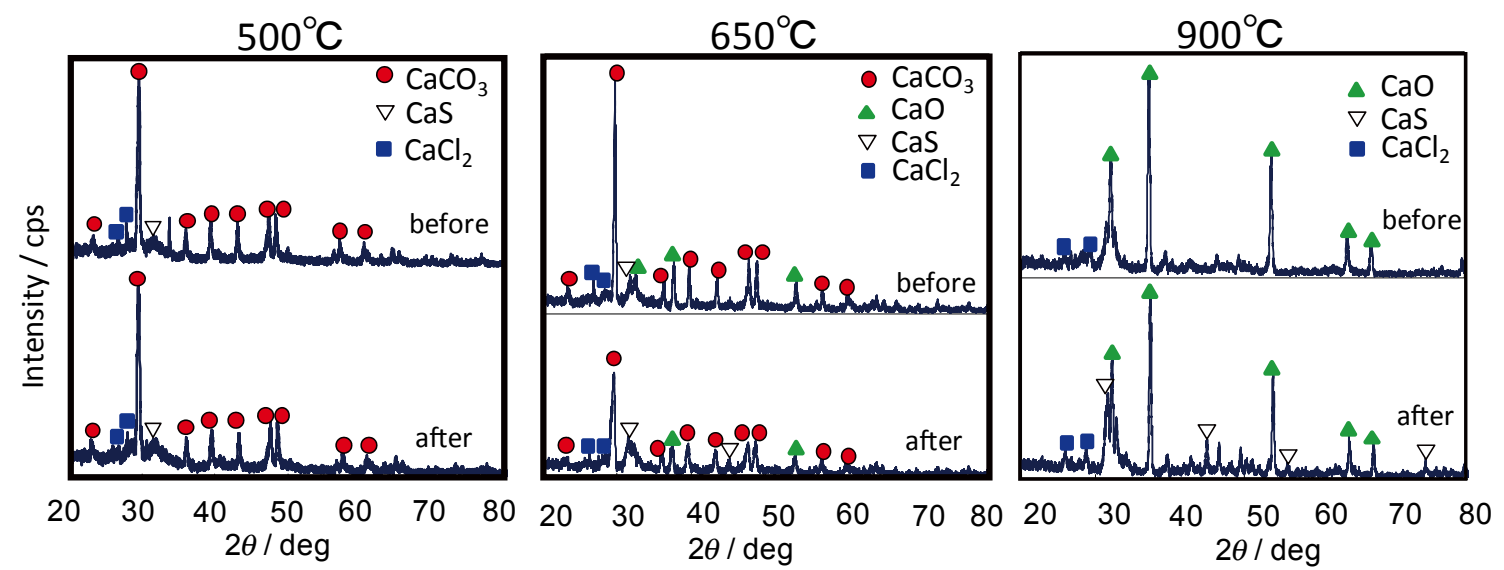

Fig. 8 XRD patterns of CC char before and after pyrolysis with CC char Pyrolysis temperature: (a) $500{ }^{\circ} \mathrm{C}$; (b) $650{ }^{\circ} \mathrm{C}$; and (c) $900{ }^{\circ} \mathrm{C}$.

これより，触媒層に設置した CCチャー中のカルシウム の主な化学形態は, PCの熱分解において生成されるガス, スス，タールと反応することによって，大きく変化するこ とはなかった. しかし, 熱分解温度 $650{ }^{\circ} \mathrm{C}$ では, $\mathrm{CaCl}_{2}$ $\left(27^{\circ}\right)$ と $\mathrm{CaS}\left(31^{\circ}\right.$ と $\left.45^{\circ}\right)$ に由来するピークが, $900{ }^{\circ} \mathrm{C}$ で は, $\mathrm{CaCl}_{2}\left(27^{\circ}\right)$ と $\mathrm{CaS}\left(31^{\circ}, 45^{\circ}, 56^{\circ}, 74^{\circ}\right)$ に由来す るピークが明らかに増加した。

したがって, PCから放出された硫黄と塩素が CCチャー 中のカルシウムと反応している可能性が高いものと推察さ れ，バイオマスガスの生成過程で，脱硫・脱塩に用いられ る $\mathrm{CaCO}_{3}$ や $\mathrm{Ca}(\mathrm{OH})_{2}$ と同様に $\mathrm{CC}$ チャーも利用できるこ とが示唆された

\section{4 結 論}

本実験の結果より, PC 及び CC の熱分解による塩素, 硫 黄の放出挙動については, 熱分解温度の上昇に伴い, ガス, スス，タールに放出される割合が高くなることが分かっ た.すなわち，より低温でコンポストの熱分解を行うこと で，塩素，硫黄の放出を抑えることができる，また，ガス 化炬内で塩素, 硫黄が過剩に放出される場合は, 熱分解後 の CCチャーがそれらの吸着剤として利用できることを示 した。すなわち，脱硫・脱塩剤をガス化炉内に封入するこ となく，熱分解後に回収した残椬を炉内に投入するだけで コンポストの脱硫・脱塩が可能であることを実証した．た だし，熱分解温度が低すぎると，タールが多く生成され, CC チャーによる脱硫・脱塩効率が極端に低下する点は, 本研究にかかわる今後の検討課題としたい.

\section{謝 辞}

本研究は, (独) 科学技術振興機構（JST）の群馬県地域 結集型開発プログラムの「環境に調和した地域産業創出プ ロジェクト」において実施された.

\section{文献}

1) 農林水産省：“家畜排せつ物の発生と管理の状況”, $<$ http://www.maff.go.jp>, (2013 年 3 月 22 日 $ア$ クセス).

2) 斎藤雅典：日本土壤肥料学雑誌, 73, 453 (2002).

3) 群馬県庁：“群馬県家畜排せつ物利用促進計画 (平 成 20 年 5 月)”, < http://www.pref.gunma.jp>, (2013 年 2 月 23 日アクセス).

4) H. Jorgensen : Livest. Sci., 109, 216 (2007).

5) 松中照夫, 成瀬往代, 熊井実鈴：日本土䁃肥料科 学雑誌, 73, 297 (2002).

6) 木田建次：“生産的変換技術 (第 2 章), バイオマス エネルギー利用の最新技術”，湯川英明監修，p. 88， (2001), (シーエムシー).

7) 李 玉友: 農業土木学会誌, 73, 739 (2005).

8) X. B. Xiao, D. D. Le, L. Y. Li, X. L. Meng, J. P. Cao, K. Morishita, T. Takarada: Biomass Bioenerg., 34, 1505 (2010).

9) S. Priyadarsan, K. Annamalai, J. M. Sweeten, S. Mukhtar, M. T. Holtzapple : Trans. ASAE, 47, 1689 (2004).

10) S. Y. Zhang, X. J. Wang, J. P. Cao, T. Takarada : Bioresour. Technol., 102, 2033 (2011).

11) X. Xiao, D. D. Le, K. Morishita, S. Zhang, L. Li, T. Takarada : Fuel Process. Technol., 91, 895 (2010).

12) 柳田高志, 美濃輪智朗, 清水嘉久, 松村幸彦, 野田 洋二：エネルギー・資源学会論文誌，30，10 (2009).

13) 薬師堂謙一：畜産環境情報, 36, 3 (2007).

14) X. Xiao, D. D. LE, K. Morishita, L. LI, T. Takarada : Bioresour. Technol., 100, 36 (2009).

15) 協同飼料株式会社: “配合飼料とその原料”, $<$ http://www.kyodo-shiryo.co.jp>，(2012 年 8 月 25 日アクセス).

16) I. González, E. Galán, A. Miras : Appl. Cray Sci., 32, 153 (2006).

17) X. Wei, Y. Wang, D. Liu, H. Sheng, W. Tian, Y. Xiao : Energy Fuels, 23, 1390 (2009).

18) H. Kuramochi, W. Wu, K. Kawamoto : Fuel, 84, 377 (2005).

19) G. Fraissler, M. Jöller, T. Brunner, I. Obernberger : Chem. Eng. Process., 48, 380 (2009).

20) M. J. H. Snow, J. P. Longwell, A. F. Sarofim : Ind. 
Eng. Chem. Res., 27, 268 (1988).

21) 劉 貴慶, 板谷義紀, 山崎量平, 山口正隆, 近藤元 博, 森 滋勝: 化学工業論文集, 27, 100 (2001).

22) S. Cheah, Y. O. Parent, W. S. Jablonski, T. Vinzant, J.

L. Olstad : Fuel, 97, 612 (2012).
23) Y. H. Zhang, D. J. Draelants, K. Engelen, GV. Baron : J. Chem. Technol. Biotechnol., 78, 265 (2003).

24) L. L. Baxter, T. R. Miles, T. R. Miles Jr., B. M. Jenkins, T. Milne, D. Dayton, R. W. Bryers, L. L. Oden : Fuel Process. Technol., 54, 47 (1998).

Analysis on Release Behavior of Sulfur and Chlorine in

Low Temperature Gasification Process of Livestock Manure Composts and Application of Solid Residue to Desulfurization and Desalinization

\author{
Masanobu Mori ${ }^{\circledR 1}$, Takuhiro Kamimura ${ }^{1}$, Fumine GunjI ${ }^{1}$, Kei-ichi Kaneko ${ }^{1,2}$, \\ Kazuyoshi SATO $^{1}$, Takayuki TAKARADA ${ }^{1}$ and Hideyuki ITABASHI ${ }^{1}$ \\ ${ }^{\circledR}$ E-mail : mori@gunma-u.ac.jp
}

${ }^{1}$ Faculty of Science and Technology, Gunma University, 1-5-1, Tenjin-cho, Kiryu-shi, Gunma 376-8515

${ }^{2}$ Kinsei Sangyo Co., Ltd., 788, Yanaka-machi, Takasaki-shi, Gunma 370-1203

(Received April 1, 2013; Accepted April 23, 2013)

Herein, we report on the release behaviors of sulfur and chlorine in the gasification process of livestock manure composts, i.e., pig feces compost (PC) and chicken droppings compost (CC) by pyrolysis under reduction atmosphere at low temperatures $\left(<650{ }^{\circ} \mathrm{C}\right)$. The pyrolysis of the composts generates gaseous species, tar and soot, containing sulfur and chlorine. The amounts of sulfur and chlorine released from the composts were dependent on increases of the pyrolysis temperatures. More than $80 \%$ of sulfur from PC and $39-56 \%$ from CC were released as gas, tar and soot. In contrast, chlorine released after the pyrolysis of PC and CC was less than $20 \%$. This was considered to be mainly due to the chemical forms of sulfur and chlorine in the composts. Furthermore, the CC char, which contained a large amount of calcium, could be applied as the adsorbent for sulfur and chlorine in the gas, tar, and soot released by the pyrolysis of PC. This would be due to interactions of sulfur and chlorine to calcium in the CG char.

Keywords: gasification; livestock manure compost; sulfur; chlorine; recycle. 